\title{
The management of persistent adnexal masses in cesarean section
}

\author{
Aşkın Evren Güler ${ }^{1}$ (D) , Zeliha Çiğdem Demirel Güler ${ }^{1}$ iD , Özge Şehirli Kinci² \\ ${ }^{\prime}$ Obstetrics and Gynecology Clinic, Koru Ankara Hospital, Ankara, Turkey \\ ${ }^{2}$ Department of Obstetrics and Gynecology, Muğla Sıtkı Koçman University Training and Research Hospital, Mŭ̆la, Turkey
}

\begin{abstract}
Objective: Our aim is to reveal the management of pregnant women in the antenatal period or during cesarean section (CS) who are found to have adnexal masses during antenatal period or CS and discuss the consequences thereof based on the literature findings.
\end{abstract}

Methods: The data of 2364 patients with scheduled or emergency CS performed at Koru Ankara Hospital Obstetrics and Gynecology Clinic between June 2013 and December 2018 were retrospectively reviewed. The largest diameter measured in the pathology results was taken as the diameter of the masses.

Results: Twenty-six (1.09\%) patients were found to have adnexal masses. None of the patients had an adnexal mass known before pregnancy. All cases of fibroids are excluded. Eighteen patients were diagnosed in the antenatal period, in the pregnancy week $10.5 \pm 1.2$ on average (69\%), and no changes were observed in the masses during pregnancy. In 8 cases, however, adnexal masses were detected incidentally during CS (31\%). Masses found in 5 out of 26 patients were paraovarian or paratubal (19.2\%) whereas the remaining 21 patients were identified to have ovarian masses. The histological types of these ovarian masses can be listed based on their prevalence as follows: mature cystic teratoma (34.6\%), serous cystadenoma (15.4\%) and endometrioma (15.4\%), mucinous cyst (11.5\%), and fibroma (3.9\%). The masses, which tend to be the largest in size, are serous cystadenomas having an average size of $62.64 \pm 22.18 \mathrm{~mm}$.

Conclusion: Adnexal masses in pregnancy can be monitored considering the patient's clinical findings and the presence of a malignancy suspicion or can be operated in the appropriate trimester. Masses observed during cesarean section may be removed and sent for a pathological examination, depending on the surgeon's decision.

Keywords: Adnexal mass, pregnancy, cystectomy.

\section{Özet: Sezaryen doğumda persistan adneksiyal kitlelerin yönetimi}

Amaç: Amacımız, antenatal dönemde veya sezaryen doğum esnasında adneksiyal kitleleri olduğu tespit edilen gebelerin antenatal dönemdeki veya sezaryen doğum esnasındaki yönetimini ortaya koymak ve literatür bulguları ışığında bunların sonuçlarını tartısmaktır.

Yöntem: Haziran 2013 ile Aralık 2018 tarihleri arasında Koru Ankara Hastanesi Kadın Hastalıkları ve Doğum Kliniğinde sezaryen doğumu planlanmış veya acil sezaryen doğum gerçekleştirmiş 2364 hastanın verileri retrospektif olarak incelenmiştir. Patoloji sonuçlarında ölçülen en büyük çap, kitlelerin çapı kabul edilmiştir.

Bulgular: Yirmi altı (\%1.09) hastada adneksiyal kitle bulundu. Hastaların hiçbirinde gebelik öncesinde bilinen adneksiyal kitle yoktu. Tüm fibroid olguları çalışma dışı bırakıldı. On sekiz hasta antenatal dönemde ortalama $10.5 \pm 1.2$ gebelik haftasında (\%69) tanı alırken, gebelik esnasında kitlelerde hiçbir değişiklik gözlemlenmedi. Ancak 8 (\%31) olguda adneksiyal kitleler sezaryen doğum esnasinda tesadüfen tespit edildi. Yirmi altı hastanın 5'inde (\%19.2) bulunan kitleler paraovaryen veya paratubal iken, kalan 21 hastada ovaryen kitleler bulundu. Bu ovaryen kitlelerin histolojik tipleri, prevalansları temel alınarak aşağıdaki gibi listelenebildi: matür kistik teratom (\%34.6), seröz kistadenom (\%15.4) ve endometriyom (\% 15.4), müsinöz kist (\% 11.5) ve fibrom (\%3.9). Büyük boyutlu olma eğilimindeki kitleler, ortalama $62.64 \pm 22.18 \mathrm{~mm}$ boyut ile ciddi kistadenomlar olarak saptandi.

Sonuç: Gebelikte adneksiyal kitleler, hastanın klinik bulguları ve malignite şüphesinin varlığı dikkate alınarak takip edilebilir ve uygun trimesterde opere edilebilir. Sezaryen doğum esnasında gözlemlenen kitleler alınarak, cerrahın kararına bağlı olarak patolojik incelemeye gönderilebilir.

Anahtar sözcükler: Adneksiyal kitle, gebelik, kistektomi.

Correspondence: Özge Şehirli Kinci, MD. Department of Obstetrics and Gynecology, Muğla Sttkı Koçman University Training and Research Hospital, Muğla, Turkey. e-mail: drozgesehirlikinci@gmail.com / Received: May 25, 2019; Accepted: August 31, 2019

Please cite this article as: Güler AE, Demirel Güler ZÇ, Şehirli Kinci Ö. The management of persistent adnexal masses in cesarean section. Perinatal Journal 2019;27(2):56-61. doi:10.2399/prn.19.0272002 


\section{Introduction}

The incidence of adnexal masses in pregnancy ranges between $1 / 41$ and $1 / 1500 .{ }^{[1]}$ Only $3 \%$ of those masses are malignant. ${ }^{[2]}$ Mature cystic teratoma is the most prevalent type, with an incidence rate of $50 \% \cdot{ }^{[3]}$ Due to the more widespread use of ultrasonography and other imaging methods as well as the increasing rate of cesarean section (CS), adnexal masses are now detected more frequently during pregnancy. ${ }^{[4,5]}$

However, management of persistent ovarian cysts detected in pregnancy and incidental adnexal masses encountered during cesarean section is debated. Conditions such as torsions, ruptures, or progress of tumor stage in malignant masses which may potentially cause both maternal and fetal complications may occur throughout pregnancy, especially in the advancing weeks of pregnancy. ${ }^{[6]}$ Surgeons, on the other hand, are concerned that surgical interventions may lead to many complications, in particular, preterm delivery. ${ }^{[1]}$

Our aim with this retrospective study is to reveal the management of pregnant women in the antenatal period or during CS who were found to have adnexal masses during antenatal period or CS and discuss the consequences thereof based on the literature findings.

\section{Methods}

The data of 2364 patients with scheduled or emergency CS performed at Koru Ankara Hospital Obstetrics and Gynecology Clinic between June 2013 and December 2018 were retrospectively reviewed. Ethical approval for the study was obtained from the Ethics Committee, Koru Ankara Hospital (Ethics Committee protocol code: 13/03/2019-38). The study was conducted in accordance with the Helsinki declaration. CSs were performed under spinal or general anesthesia by several obstetricians in a single center. All CS and cystectomy/oophorectomy procedures were performed by obstetrics and gynecology specialists. Exclusion criterion for the study was the presence of adnexal mass before the pregnancy period. The largest diameter measured in the pathology results was taken as the diameter of the masses.

After the CS was completed, cystectomy/oophorectomy decision was made, considering the experience of the surgeon, for patients who were found to have adnexal masses. Cystectomy was carried out by stripping the cyst capsule off from the healthy ovarian tissue after a dissection was made on the ovarian tissue through cautery. Oophorectomy was performed by clamping, cutting and then suturing with $0 \mathrm{Vicryl}^{\circledR}$ the suspensory ligament of ovary and ligament of ovary, in given order. Due to the risk of malignancy, cystectomy/oophorectomy procedures were performed without rupturing the cysts. Pathologic examination (frozen section) was not performed in any case. Final pathological examination expected for other surgeries.

Age, gravidity, parity, week of delivery, CS indications, the period when mass was detected (antenatal, intra-cesarean), and mass removal technique (cystectomy/oophorectomy) were evaluated for all patients retrospectively. Sizes of cysts/ovaries and histopathological examination results were followed up through pathology reports. Cysts/ovaries were evaluated by the same pathologist.

All analyses were conducted using SPSS 22.0 (SPSS Inc., Chicago, IL, USA).

\section{Results}

Between June 2013 and December 2018, 2364 patients underwent CS at Koru Ankara Hospital, in 26 (1.09\%) of whom adnexal masses were detected. None of the patients had an adnexal mass known before pregnancy. Diagnosis was made during the antenatal period in 18 patients $(69 \%)$, at gestational Week $10.5 \pm 1.2$, on average, who had no changes in their masses during the rest of pregnancy. In 8 cases (31\%), however, adnexal masses were detected incidentally during CS. Mean age of delivery of the pregnant women who were found to have adnexal masses were 30.2 , mean parity were 2 , and mean week were 38 weeks and 3/7 days, respectively.

Indications for CS included 15 past CS $(57.7 \%), 2$ fetal distress (7.7\%), 3 breech presentation (11.5\%), 3 cephalopelvic disproportion (11.5\%), 1 placenta previa (3.9\%), and 2 multiple pregnancy cases (Table 1). Only one of 26 patients underwent oophorectomy (3.9\%) whereas 25 patients $(96.1 \%)$ had cystectomy surgery (Table 2).

Masses found in $5(19.2 \%)$ out of 26 patients were paraovarian or paratubal whereas the remaining 21 patients were identified to have ovarian masses. The histological types of these ovarian masses, in order of fre- 
quency, were as follows: mature cystic teratoma (34.6\%) (Fig. 1 and 2), serous cystadenoma (15.4\%) (Fig. 3) and endometrioma (15.4\%), mucinous cyst (11.5\%), and fibroma $(3.9 \%)$. The masses, which tend to be the largest in size, are serous cystadenomas having an average size of $62.64 \pm 22.18 \mathrm{~mm}$. Endometrioma was the only case treated with oophorectomy (Table 2).

\section{Discussion}

The incidence of adnexal masses in pregnancy ranges between $1 / 41$ and $1 / 1500 .{ }^{[1]}$ The most common types are mature cystic teratoma, cystadenoma, and functional cysts. ${ }^{[3]}$ The incidence and histological types identified in our study were comparable to those available in the literature. In our case series, the incidence was around $1 \%$ with mature cystic teratoma being the most common histological type (34.6\%). Adnexal masses in pregnancy usually have an asymptomatic course. Complications such as torsion and cyst rupture may occur in cysts larger than $5 \mathrm{~cm} .{ }^{[7,8]}$ In fact, the majority of the adnexal cysts in pregnancy get resorbed before the 16th week. Technological advancements in imaging methods not only made the detection of adnexal masses easier but also increased the dilemmas associated with the management of such masses. ${ }^{[4]}$ In their study, Lee et al. supported the conservative management of adnexal masses in pregnancy. ${ }^{[9]}$ Risk of malignancy in masses with unchanging or growing sizes should be noted: $0.6 \%$ of such masses are known to have malignancy risk. ${ }^{[10]}$ Malignancy was not detected in our patients. Sherard et al. found a $13 \%$ malignancy incidence in persistent adnexal masses associated with pregnancy and the malignancy rate to be $1 / 47411^{[11]}$
Table 1. Distribution of the indications for cesarean section.

\begin{tabular}{lcc} 
Indication for cesarean section & Number $(\mathbf{n})$ & Percentage (\%) \\
Previous caesarean delivery & 15 & 57.7 \\
Fetal distress & 2 & 7.7 \\
Breech presentation & 3 & 11.5 \\
Cephalopelvic disproportion & 3 & 11.5 \\
Placenta previa & 1 & 3.9 \\
Multiple pregnancy & 2 & 7.7 \\
Total & 36 & 100 \\
\hline
\end{tabular}

MRI and ultrasonography have an important place in the imaging of adnexal masses during pregnancy. ${ }^{[4]}$ Ultrasonography is very helpful in understanding the content and nature of the mass in the first-stage evaluation. It helps elaborating as to whether the mass is solid or cystic, whether or not it has a septum, and provides further information about the structure of the cyst wall, and content of the cyst. MRI may be used when ultrasonography is inadequate. For all of our patients, the evaluation was performed through ultrasonography. Adnexal masses were detected in 18 patients during antenatal monitoring, and during follow-up, likewise, ultrasonography was employed while MRI was not needed.

Intervention to the adnexal masses detected in pregnancy should be considered during pregnancy only in the presence of suspicion of malignancy, symptomatic mass, and persistent adnexal mass greater than $8-10 \mathrm{~cm} .{ }^{[12]}$ In our study, none of the patients was operated during pregnancy since none of them met the foregoing criteria. Small ovarian cysts are usually managed conservatively. Conventionally, laparotomy is

Table 2. Distribution of the histological types of cysts.

\begin{tabular}{|c|c|c|c|c|c|c|}
\hline \multirow[b]{2}{*}{ Histological type } & \multirow[b]{2}{*}{ n (\%) } & \multirow[b]{2}{*}{$\begin{array}{l}\text { Cyst size } \\
\text { (mm) }\end{array}$} & \multicolumn{2}{|c|}{ Treatment } & \multicolumn{2}{|c|}{ Time of detection } \\
\hline & & & $\begin{array}{c}\text { Cystectomy } \\
\text { n (\%) }\end{array}$ & $\begin{array}{c}\text { Oophorectomy } \\
\text { n (\%) }\end{array}$ & $\begin{array}{c}\text { Antenatal } \\
n(\%)\end{array}$ & $\begin{array}{c}\text { Intra-cesarean } \\
n(\%)\end{array}$ \\
\hline Mature cystic teratoma & $9(34.6)$ & $41.24 \pm 12.1$ & $9(34.61)$ & $0(0)$ & $5(19.23)$ & $4(15.38)$ \\
\hline Serous cystadenoma & $4(15.4)$ & $62.64 \pm 22.18$ & $4(15.38)$ & $0(0)$ & $4(15.38)$ & $0(0)$ \\
\hline Mucinous cystadenoma & $3(11.5)$ & $32.56 \pm 18.21$ & $3(11.53)$ & $0(0)$ & $2(7.69)$ & $1(3.84)$ \\
\hline Endometrioma & $4(15.4)$ & $51.92 \pm 10.62$ & $3(11.53)$ & $1(3.84)$ & $3(11.53)$ & $1(3.84)$ \\
\hline Paratubal-paraovarian cyst & $5(19.2)$ & $44.18 \pm 11.26$ & $5(19.23)$ & $0(0)$ & $4(15.38)$ & $1(3.84)$ \\
\hline Fibroma & $1(3.9)$ & 24 & $1(3.84)$ & $0(0)$ & $0(0)$ & $1(3.84)$ \\
\hline
\end{tabular}



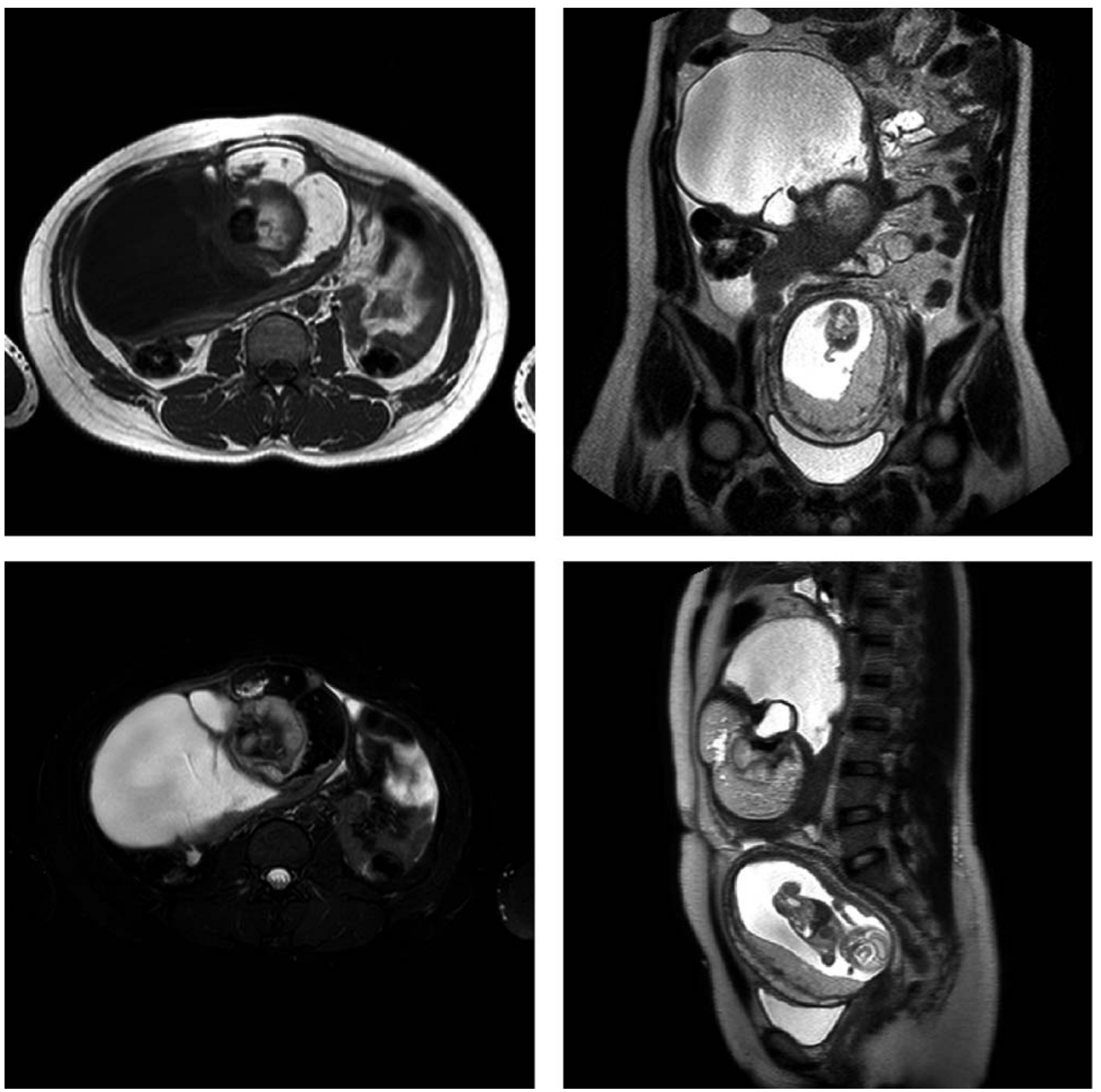

Fig. 1. 16-weeks pregnancy + mature cystic teratoma (MRI scan).

recommended if the mass is greater than $6 \mathrm{~cm}$, is solid and bilateral or persists in the second trimester. ${ }^{[3,12]}$ Elective surgery is usually planned in the second trimester, after week 18, in order to reduce the risk of abortus. ${ }^{[13]}$ In the event of incidentally detected masses, removal is recommended, especially for those greater than $5 \mathrm{~cm}$, during CS which already involves a laparotomy and is suggested to have no undesired effects on mortality or morbidity. ${ }^{[14]}$ In our study, we performed cystectomy/oophorectomy in order to obtain a histopathological result (risk of malignancy) in all cases, regardless of the size of the masses. 

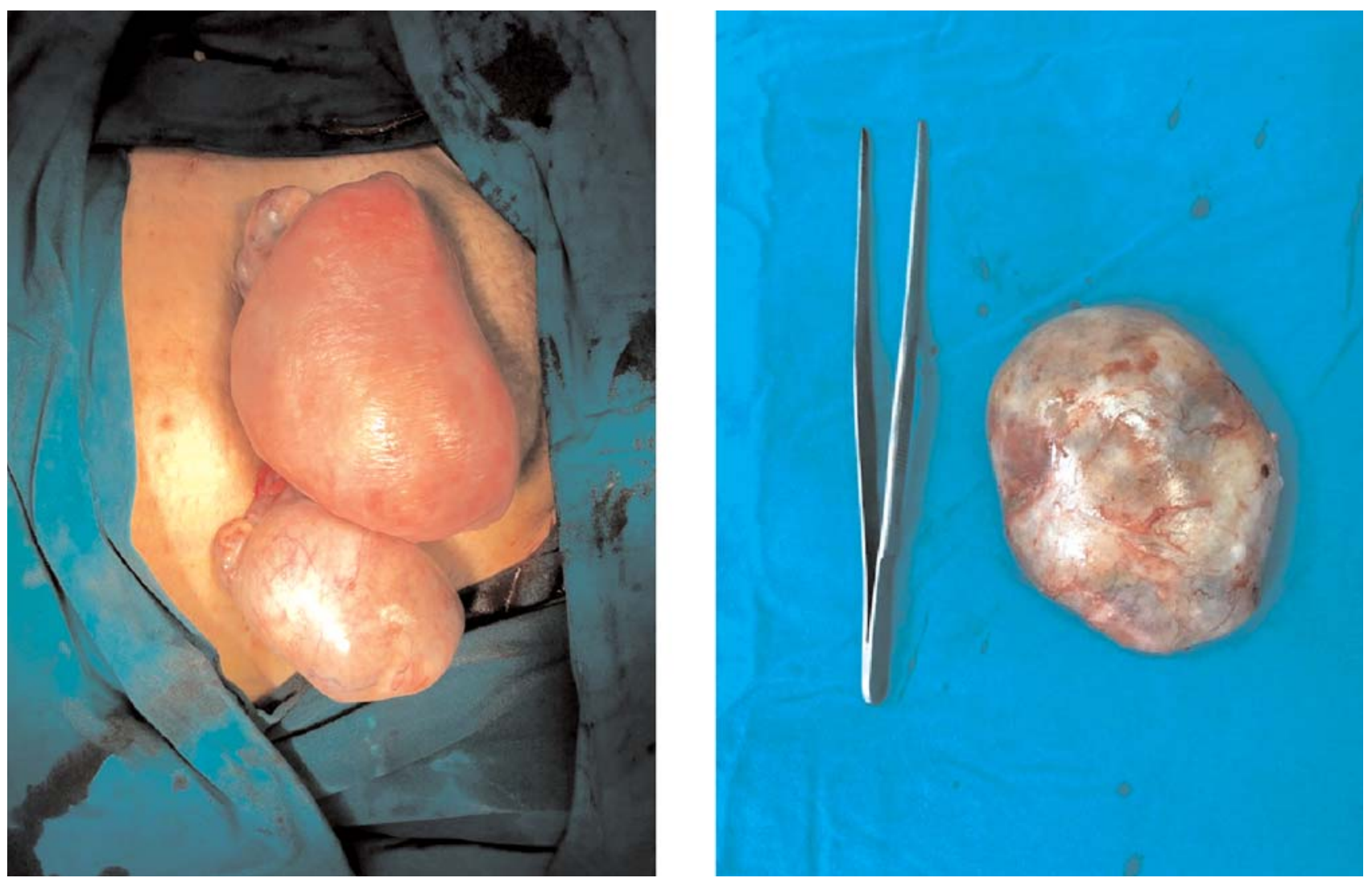

Fig. 2. Mature cystic teratoma in cesarean section.
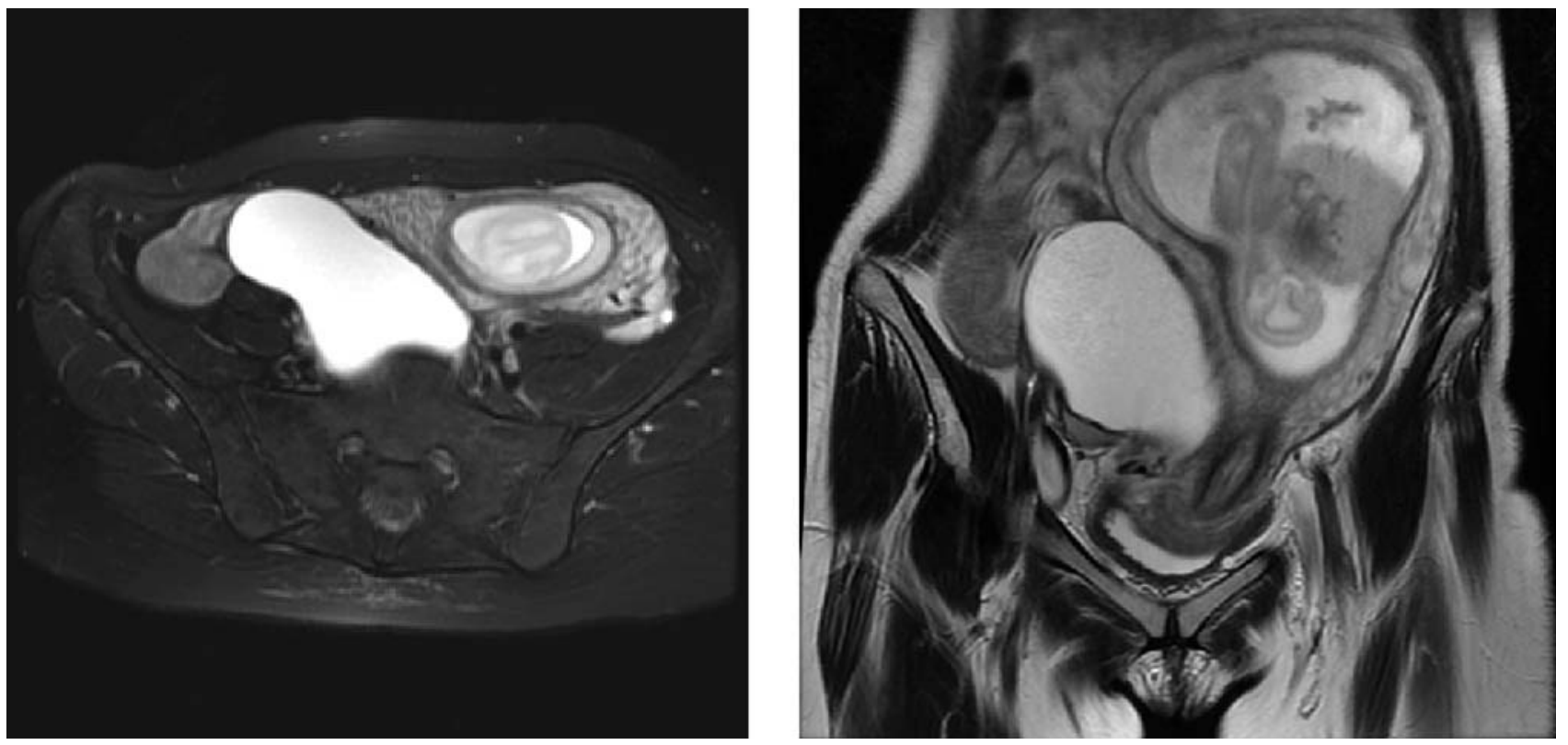

Fig. 3. 13-weeks pregnancy + serous cystadenoma (MRI scan). 


\section{Conclusion}

In adnexal masses during pregnancy, close follow up is a way of management, but patient's clinical findings and symptoms or suspicion of malignancy are indications of surgery. Masses observed during CS may be removed and sent for a pathological examination, depending on the surgeon's decision.

Conflicts of Interest: No conflicts declared.

\section{References}

1. Ye P, Zhao N, Shu J, Shen H, Wang Y, Chen L, et al. Laparoscopy versus open surgery for adnexal masses in pregnancy: a meta-analytic review. Arch Gynecol Obstet 2019; 299:625-34.

2. Hermans RH, Fischer DC, van der Putten HW, Van De Putte G, Einzmann T, Vos MC, et al. Adnexal masses in pregnancy. Onkologie 2003;26:167-72.

3. Whitecar MP, Turner S, Higby MK. Adnexal masses in pregnancy: a review of 130 cases undergoing surgical management. Am J Obstet Gynecol 1999;181:19-24.

4. Chiang $\mathrm{G}$, Levine D. Imaging of adnexal masses in pregnancy. J Ultrasound Med 2004;23:805-19.

5. Ulubay M, Öztürk M, Fidan U, Keskin U, Firatlıgil FB, Kıncı $M F$, et al. Skin incision lengths in caesarean section. Çukurova Medical Journal 2016;41:82-6.
6. Roberts, JA. Management of gynecologic tumors during pregnancy. Clin Perinatol 1983;10:369-82.

7. Munnell EW. Primary ovarian cancer associated with pregnancy. Clin Obstet Gynecol 1963;30:983-93.

8. Grimes WH, Jr, Bartholomew RA, Colvin ED, Fish JS, Lester WM. Ovarian cyst complicating pregnancy. Am J Obstet Gynecol 1954;68:594-605.

9. Lee GS, Hur SY, Shin JC, Kim SP, Kim SJ. Elective vs. conservative management of ovarian tumors in pregnancy. Int $\mathrm{J}$ Gynaecol Obstet 2004;85:250-4.

10. Duic Z, Kukura V, Ciglar S, Podobnik M, Podgajski M. Adnexal masses in pregnancy: a review of eight cases undergoing surgical management. Eur J Gynaecol Oncol 2002;23:1334.

11. Sherard GB, 3rd, Hodson CA, Williams HJ, Semer DA, Hadi HA, Tait DL. Adnexal masses and pregnancy: a 12-year experience. Am J Obstet Gynecol 2003;189:358-62; discussion 62-3.

12. Schmeler KM, Mayo-Smith WW, Peipert JF, Weitzen S, Manuel MD, Gordinier ME. Adnexal masses in pregnancy: surgery compared with observation. Obstet Gynecol 2005; 105:1098-103.

13. Platek DN, Henderson CE, Goldberg GL. The management of a persistent adnexal mass in pregnancy. Am J Obstet Gynecol 1995;173:1236-40.

14. Dede M, Yenen MC, Yilmaz A, Goktolga U, Baser I. Treatment of incidental adnexal masses at cesarean section: a retrospective study. Int J Gynaecol Obstet 2007;17:339-41.

Bu makalenin kullanım izni Creative Commons Attribution-NoCommercial-NoDerivs 3.0 Unported (CC BY-NC-ND3.0) lisansı aracılı̆̆ılyla bedelsiz sunulmaktadır. / This work is licensed under the Creative Commons Attribution-NonCommercial-NoDerivs 3.0 Unported (CC BY-NC-ND3.0) License. To view a copy of this license, visit http://creativecommons.org/licenses/by-nc-nd/3.0/ or send a letter to Creative Commons, PO Box 1866, Mountain View, CA 94042, USA. 